\title{
Influence of altitude on ozone levels and variability in the lower troposphere: a ground-based study for western Europe over the period 2001-2004
}

\author{
A. Chevalier ${ }^{1}$, F. Gheusi ${ }^{1}$, R. Delmas ${ }^{1}$, C. Ordóñez ${ }^{1}$, C. Sarrat $^{2}$, R. Zbinden ${ }^{1}$, V. Thouret ${ }^{1}$, G. Athier ${ }^{1}$, and \\ J.-M. Cousin ${ }^{1}$ \\ ${ }^{1}$ Laboratoire d'Aérologie, Toulouse, France \\ ${ }^{2}$ Centre National de Recherches Atmosphériques, Toulouse, France
}

Received: 8 November 2006 - Published in Atmos. Chem. Phys. Discuss.: 29 January 2007

Revised: 27 July 2007 - Accepted: 12 August 2007 - Published: 22 August 2007

\begin{abstract}
The PAES (French acronym for synoptic scale atmospheric pollution) network focuses on the chemical composition (ozone, $\mathrm{CO}, \mathrm{NO}_{\mathrm{x} / \mathrm{y}}$ and aerosols) of the lower troposphere $(0-3000 \mathrm{~m})$. Its high-altitude surface stations located in different mountainous areas in France complete the lowaltitude rural MERA stations (the French contribution to the european program EMEP, European Monitoring and Evaluation Program). They are representative of pollution at the scale of the French territory because they are away from any major source of pollution.

This study deals with ozone observations between 2001 and 2004 at 11 stations from PAES and MERA, in addition to 16 elevated stations located in mountainous areas of Switzerland, Germany, Austria, Italy and Spain. The set of stations covers a range of altitudes between 115 and $3550 \mathrm{~m}$. The comparison between recent ozone mixing ratios to those of the last decade at Pic du Midi (2877 m), as well as trends calculated over 14-year data series at three high-altitude sites in the Alps (Jungfraujoch, Sonnblick and Zugspitze) reveal that ozone is still increasing but at a slower rate than in the 1980s and 1990s.

The 2001-2004 mean levels of ozone from surface stations capture the ozone stratification revealed by climatological profiles from the airborne observation system MOZAIC (Measurement of OZone and water vapour by Airbus Inservice airCraft) and from ozone soundings above Payerne (Switzerland). In particular all data evidence a clear transition at about $1000-1200 \mathrm{~m}$ a.s.l. between a sharp gradient below (of the order of $+30 \mathrm{ppb} / \mathrm{km}$ ) and a gentler gradient $(+3 \mathrm{ppb} / \mathrm{km})$ above. The same altitude $(1200 \mathrm{~m})$ is also found to be a threshold regarding how well the ozone levels
\end{abstract}

at the surface stations agree with the free-tropospheric reference (MOZAIC or soundings). Below the departure can be as large as $40 \%$, but suddenly drops within $15 \%$ above. For stations above $2000 \mathrm{~m}$, the departure is even less than $8 \%$. Ozone variability also reveals a clear transition between boundary-layer and free-tropospheric regimes around $1000 \mathrm{~m}$ a.s.l. Below, diurnal photochemistry accounts for about the third of the variability in summer, but less than $20 \%$ above - and at all levels in winter - where ozone variability is mostly due to day-to-day changes (linked to weather conditions or synoptic transport). In summary, the altitude range $1000-1200 \mathrm{~m}$ clearly turns out in our study to be an upper limit below which specific surface effects dominate the ozone content.

Monthly-mean ozone mixing-ratios show at all levels a minimum in winter and the classical summer broad maximum in spring and summer - which is actually the superposition of the tropospheric spring maximum (April-May) and regional pollution episodes linked to persistent anticyclonic conditions that may occur from June to September. To complement this classical result it is shown that summer maxima are associated with considerably more variability than the spring maximum. This ensemble of findings support the relevance of mountain station networks such as PAES for the long-term observation of free-tropospheric ozone over Europe.

Correspondence to: F. Gheusi

(ghef@aero.obs-mip.fr)

Published by Copernicus Publications on behalf of the European Geosciences Union. 


\section{Introduction}

Tropospheric ozone is known as a pollutant since the 1950s, causing harm to human health and ecosystems (e.g., Brunekreef and Holgate (2002)). It also plays a considerable role in the oxidising capacity of the troposphere and acts as the third greenhouse gas in terms of additional radiative forcing at Earth's surface (IPCC, 2001). For these reasons tropospheric ozone levels have been a matter of concern for the scientific community over the last decades. There is considerable interest in quantifying surface background ozone concentrations and associated trends as they may serve to define a lower limit with respect to reductions of ozone by control of anthropogenic precursors. Background ozone has several well documented sources, natural and anthropogenic: i) downward transport from the stratosphere, ii) local photochemical production from its major anthropogenic precursors (volatile organic compounds (VOC), carbon monoxide (CO) and nitrogen oxides $\left(\mathrm{NO}_{\mathrm{x}}\right)$ ), iii) remote production associated with long-range transport. The ozone concentration results from a complex combination of production, transport, chemical destruction and deposition.

Ancient measurements have been used to identify some trends in background levels of tropospheric ozone, as for instance in the study by Marenco et al. (1994). In their study, data from measurements at the Pic du Midi $(2877 \mathrm{~m})$ between the 1870s and 1910 and then in the 1980s were used to show that ozone mixing ratios have increased by a factor of 5 since the beginning of the twentieth century, corresponding to an exponential increase at a rate of $1.6 \% \mathrm{yr}^{-1}$. Oltmans et al. (2006) showed that ozone at Zugspitze increased by $12.6 \% /$ decade $\left(1.3 \% \mathrm{yr}^{-1}\right)$ between 1978 and 2004 . In addition, Staehelin et al. (1994) found an increase by a factor of 2 between the 1950s and the 1990s at Arosa (Switzerland). Such increase of ozone levels led European countries to subscribe promises about emissions of atmospheric primary pollutants. Two conventions were signed aiming at reducing VOCs (Geneva 1991) and $\mathrm{NO}_{\mathrm{x}}$ (Sofia 1988), two major anthropogenic ozone precursors. As a consequence of the application of these conventions, anthropogenic emissions of ozone precursors have actually decreased. In Europe, considerable emission reductions have been made since the late 1980s; they are of the order of $30 \%$ for $\mathrm{NO}_{\mathrm{x}}$ and NMVOCs and of $45 \%$ for CO for Europe as a whole (Vestreng et al., 2004; Derwent et al., 2003). Despite these reductions, most authors report an increase of background tropospheric ozone levels in the lower troposphere: for example Brönnimann et al. (2002) found an increase of the average value of around $0.5-0.9 \mathrm{ppb} \mathrm{yr}^{-1}$ for 13 Swiss stations - some of them above $1000 \mathrm{~m}$ (altitude hereafter given above see level) - between 1991 and 1999. Ordóñez (2006) found an increase by around $0.5 \mathrm{ppb} \mathrm{yr}^{-1}$ for 8 alpine stations above $1000 \mathrm{~m}$ between 1992 and 2002. Over the past decades there have been contradictory explanations about the origins of surface ozone over Europe and about the spring-time maximum (Monks,
2000). Despite a decline in episodic peak ozone mixing ratio (e.g., Derwent et al., 2004; Brönnimann et al., 2002) mean ozone mixing ratios continue to rise over Europe. Jonson et al. (2006) give some explanation about the factors affecting European tropospheric ozone trends but conclude that if the increase in winter and the decrease in the magnitude of high ozone episodes may be attributed to the decrease in ozone precursor emissions since 1990, the trend in summer is very difficult to identify from the measurements because of large inter-annual variability. Therefore long time series are needed and there are still many uncertainties about the evolution of ozone concentrations during the next two decades in the free troposphere.

Numerous studies based on surface measurements in Europe have been conducted to investigate background tropospheric ozone, from the points of view of its spatial variability (Scheel et al., 1997) and temporal variability at different scales (decadal trends, interannual variability, cycles, etc.) for both low-altitude stations (especially on coastal areas, e.g., Ribas and Peñuelas, 2004; Simmonds et al., 2004; Carslaw, 2005) and high-altitude stations (e.g., Bonasoni et al., 2000; Brönnimann et al., 2000; Schuepbach et al., 2001). In these studies the term "background ozone level" has different definitions but the common idea is an ozone level representative of the atmosphere at large spatial (e.g., hemispheric) or temporal (e.g., monthly) scales, to which natural or anthropogenic perturbations will add at smaller scales. For this purpose the considered stations are chosen away from the influence of direct pollution sources and more or less sophisticated treatments are applied to the data (running means, meteorological or trace-gas filters, etc., e.g., Zellweger et al., 2003).

Mountain stations most often fulfil the condition of being "clean sites" and hence are of particular interest. Regarding the high-altitude sites (typically above $2000 \mathrm{~m}$ ) it is often claimed that they are "above the boundary layer" or "representative of the free troposphere" by sole consideration of their elevation. However mountains considerably enhance atmospheric turbulence and affect circulation for many reasons (roughness, synoptical lifting, hydraulic effects, thermallyinduced circulations, etc.) and thus it can be hardly stated that even a high-moutain station is free from the influence of the surface without further investigation.

It is also known that background ozone level increases with height in the lower troposphere (ozone content being eroded near the surface by deposition and titration that dominates in the boundary layer at the yearly time-scale). Climatologies of vertical ozone profiles have been established from airborne in-situ measurents (balloons data, e.g., Naja et al., 2003; aircraft data, e.g., Fischer et al., 2006; Zbinden et al., 2006). Few surface-data based studies considering a network of stations in a range of altitude (e.g., Brönnimann et al., 2000) also pay some attention to this stratification. However no extensive comparison still exists in the literature between (airborne) data in the true free troposphere (i.e., unaffected 
(a)

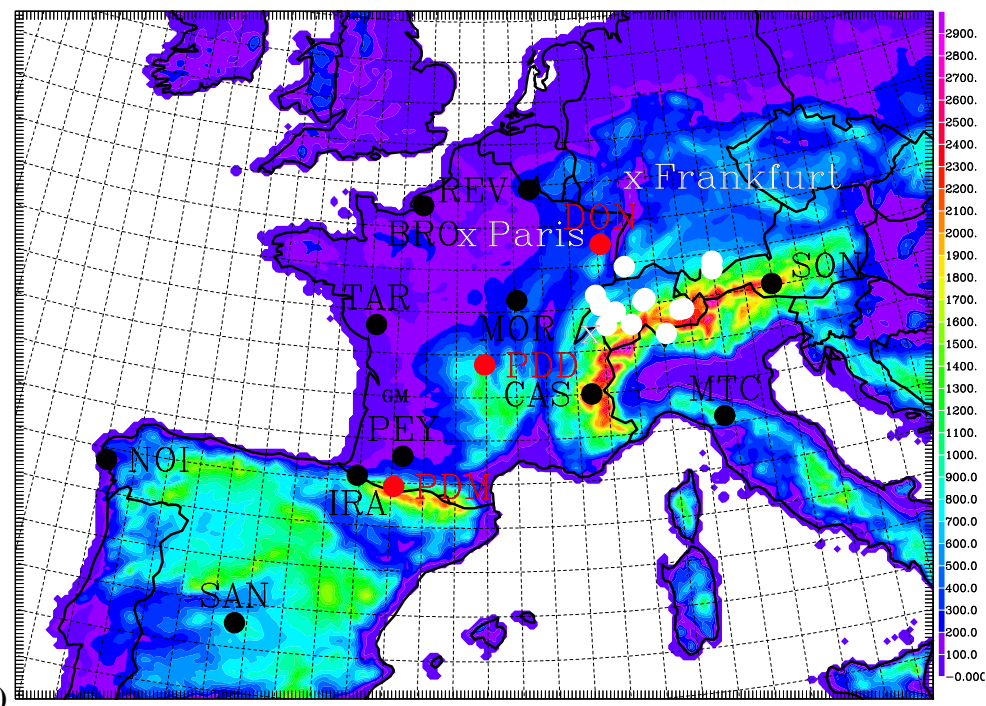

(b)

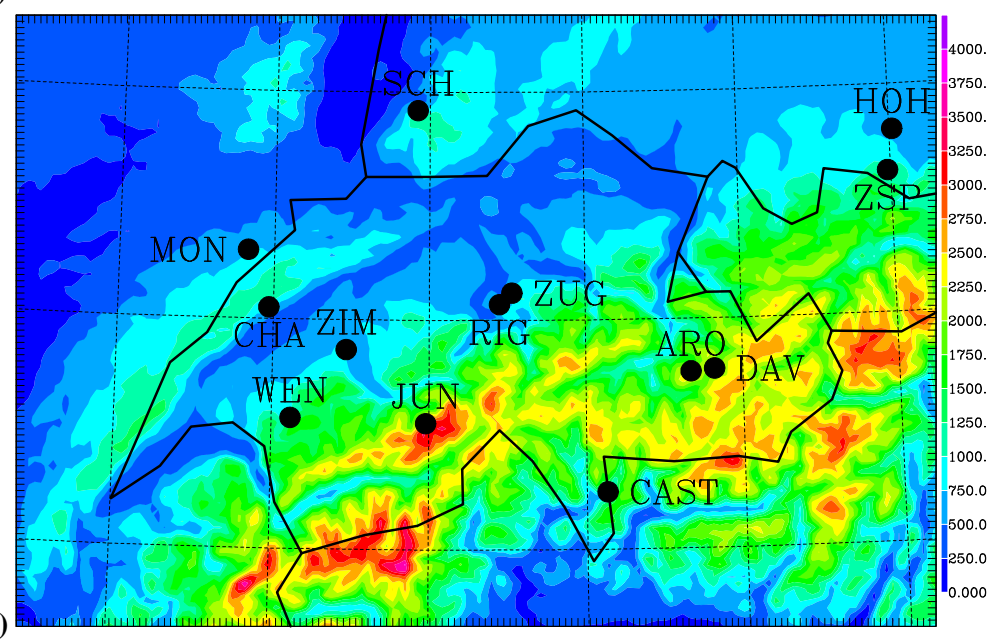

Fig. 1. (a) Location of the monitoring sites used in this study; (b) zoom on Swiss sites. See correspondence between station full names and abbreviations in Table 1.

by surface effects) and surface data at equivalent altitude.

The present paper primarily aims at contributing in this direction. Its main focus is on the investigation of the following two questions: (i) To what extent measurements from surface stations ranged in altitude can capture the stratification of background ozone in the lower troposphere? (ii) More generally to what extent an elevated surface station is representative of the free troposphere at similar altitude, in terms of ozone level and variability? For this goal we propose an analysis of ozone data between 2001 and 2004, from an extensive ensemble of 27 surface stations in mountainous or rural areas in western Europe, vertically ranged from 115 up to $3580 \mathrm{~m}$ asl, but also from climatologies of vertical ozone profiles above Frankfurt (Germany) provided by the MOZAIC system (Measurements of OZone and water vapour by Airbus In-service airCraft) and above Payerne (Switzerland) provided by balloon soundings.
Distinctly from those questions, the above database also gives us the interesting opportunity to continue the analysis by Marenco et al. (1994) with a brief discussion on the evolution of background ozone level at Pic du Midi in the last decade in light of updated trend calculations at other highaltitude sites in the Alps.

The paper is organised as follows. The networks and datasets are described in Sect. 2. Section 3 focuses on trends of tropospheric ozone at Pic du Midi and in Western Europe. Finally, Sect. 4 analyses the influence of altitude on ozone levels and variability. The conclusions are summarized in final Sect. 5 . 
Table 1. Characteristics of the measurement sites considered in this study. * IMK-IFU: Institut für Meteorologie und Klimaforschung, Forschungszentrum Karlsruhe, Germany, ** Umw.: Umweltbundesamt Österreich (Federal Environmental Agency of Austria).

\begin{tabular}{|c|c|c|c|c|c|c|}
\hline Site & Abbrev. & $\begin{array}{l}\text { Altitude } \\
\text { (m) }\end{array}$ & Coordinate & Ozone (ppb) & Description & Organisation \\
\hline Brotonne & BRO & 115 & $49^{\circ} 31 \mathrm{~N}, 0^{\circ} 44 \mathrm{E}$ & $25.3 \pm 6.3$ & Plain & MERA \\
\hline La Tardière & TAR & 143 & $46^{\circ} 39 \mathrm{~N}, 0^{\circ} 45 \mathrm{~W}$ & $30.4 \pm 7.4$ & Plain & MERA \\
\hline Peyrusse & PEY & 200 & $43^{\circ} 37 \mathrm{~N}, 0^{\circ} 11 \mathrm{E}$ & $32.8 \pm 7.3$ & Plain & MERA \\
\hline Revin & REV & 390 & $49^{\circ} 54 \mathrm{~N}, 4^{\circ} 38 \mathrm{E}$ & $30.3 \pm 8.8$ & Plain & MERA \\
\hline Morvan & MOR & 620 & $47^{\circ} 16 \mathrm{~N}, 4^{\circ} 05 \mathrm{E}$ & $31.8 \pm 7.4$ & Plain & MERA \\
\hline Noia & NOI & 685 & $42^{\circ} 44 \mathrm{~N}, 8^{\circ} 55 \mathrm{~W}$ & $40.3 \pm 6.3$ & Cantabric Mountains & WDCGG \\
\hline Montandon & MON & 746 & $47^{\circ} 18 \mathrm{~N}, 6^{\circ} 50 \mathrm{E}$ & $28.4 \pm 8.3$ & Plain & MERA \\
\hline Donon & DON & 755 & $48^{\circ} 30 \mathrm{~N}, 7^{\circ} 08 \mathrm{E}$ & $38.9 \pm 9.7$ & Vosges Mountains & PAES \\
\hline Castaneda & CAST & 770 & $46^{\circ} 15 \mathrm{~N}, 9^{\circ} 08 \mathrm{E}$ & $39.5 \pm 12.2$ & Pre-Alps & GR \\
\hline Zimmerwald & ZIM & 898 & $46^{\circ} 52 \mathrm{~N}, 7^{\circ} 28 \mathrm{E}$ & $36.6 \pm 9.8$ & Pre-Alps & $\mathrm{BE}$ \\
\hline San Pablo de los Montes & SAN & 917 & $39^{\circ} 33 \mathrm{~N}, 4^{\circ} 21 \mathrm{~W}$ & $45.2 \pm 8.7$ & Toledo Mountains & WDCGG \\
\hline Hohenpeissenberg & $\mathrm{HOH}$ & 985 & $47^{\circ} 48 \mathrm{~N}, 11^{\circ} 01 \mathrm{E}$ & $41.5 \pm 10.3$ & Pre-Alps & WDCGG \\
\hline Zugerberg & ZUG & 990 & $47^{\circ} 07 \mathrm{~N}, 8^{\circ} 32 \mathrm{E}$ & $38.3 \pm 13.7$ & Pre-Alps & IAP \\
\hline Rigi-Seebodenalp & RIG & 1031 & $47^{\circ} 04 \mathrm{~N}, 8^{\circ} 27 \mathrm{E}$ & $42.3 \pm 10.3$ & Pre-Alps & NABEL \\
\hline Chaumont & $\mathrm{CHA}$ & 1137 & $47^{\circ} 03 \mathrm{~N}, 6^{\circ} 58 \mathrm{E}$ & $43.3 \pm 9.9$ & Jura & NABEL \\
\hline Schauinsland & $\mathrm{SCH}$ & 1205 & $43^{\circ} 02 \mathrm{~N}, 7^{\circ} 55 \mathrm{E}$ & $43.4 \pm 9.1$ & Black Forest & WDCGG \\
\hline Iraty & IRA & 1400 & $47^{\circ} 55 \mathrm{~N}, 1^{\circ} 05 \mathrm{~W}$ & $46.4 \pm 5.8$ & Pyrenees & MERA \\
\hline Puy de Dôme & PDD & 1465 & $45^{\circ} 46 \mathrm{~N}, 2^{\circ} 57 \mathrm{E}$ & $44.9 \pm 9.8$ & Massif Central & PAES \\
\hline Davos & DAV & 1638 & $46^{\circ} 47 \mathrm{~N}, 9^{\circ} 49 \mathrm{E}$ & $42.0 \pm 7.1$ & Pre-Alps & NABEL \\
\hline Le Casset & CAS & 1750 & $45^{\circ} 00 \mathrm{~N}, 6^{\circ} 28 \mathrm{E}$ & $46.8 \pm 7.4$ & Alps & MERA \\
\hline Arosa & ARO & 1840 & $46^{\circ} 46 \mathrm{~N}, 9^{\circ} 40 \mathrm{E}$ & $42.3 \pm 8.2$ & Pre-Alps & GR \\
\hline Wengernalp & WEN & 1890 & $46^{\circ} 34 \mathrm{~N}, 7^{\circ} 07 \mathrm{E}$ & $46.8 \pm 7.1$ & Pre-Alps & IAP \\
\hline Monte Cimone & MTC & 2165 & $44^{\circ} 11 \mathrm{~N}, 10^{\circ} 42 \mathrm{E}$ & $52.8 \pm 9.0$ & Apennines & WDCGG \\
\hline Pic du Midi & PDM & 2877 & $42^{\circ} 55 \mathrm{~N}, 0^{\circ} 05 \mathrm{E}$ & $48.3 \pm 6.8$ & Pyrenees & PAES \\
\hline Zugspitze & ZSP & 2960 & $47^{\circ} 25 \mathrm{~N}, 10^{\circ} 59 \mathrm{E}$ & $51.5 \pm 13.7$ & Alps & WDCGG/IMK-IFU* \\
\hline Sonnblick & SON & 3106 & $47^{\circ} 03 \mathrm{~N}, 12^{\circ} 57 \mathrm{E}$ & $51.4 \pm 6.5$ & Alps & WDCGG/Umw.** \\
\hline Jungfraujoch & JUN & 3580 & $46^{\circ} 33 \mathrm{~N}, 7^{\circ} 59 \mathrm{E}$ & $53.3 \pm 6.8$ & Alps & NABEL \\
\hline
\end{tabular}

\section{Description of the observation networks and datasets}

\subsection{Surface stations}

Ozone surface data come from:

- 2 French observation networks, MERA and PAES. 8 stations belong to MERA and 3 to PAES.

- 4 Swiss organisations/networks: NABEL (National Air Pollution Monitoring Network), IAP (Institute for Applied Plant Biology), and the Swiss cantons Bern (BE) and Graubünden (GR). Data of 9 Swiss Alpine stations are provided.

- the World Data Centre for Greenhouse Gases (WDCGG: available on http://gaw.kishou.go.jp/wdcgg. html).

All the sites are displayed in Fig. 1, and details are given in Table 1. Elevations range from 115 up to $3500 \mathrm{~m}$ so that airmasses from the boundary layer to the lower free troposphere are sampled.
The MERA observation network is the French contribution to the international EMEP Program (European Monitoring and Evaluation Program, http://www.emep.int/). The 8 stations have been settled far from urban, industrial and agricultural pollution sources. The network was designed to monitor ozone concentration and atmospheric wet and dry deposition. These stations are located in both flat and mountainous areas (but none on an isolated summit), and are well distributed over the French territory. All of them are in forest and/or grassland rural areas. Their altitudes range from 115 to $1750 \mathrm{~m}$.

The PAES (french acronym for atmospheric pollution at synoptic scale) network is complementary to MERA in term of altitude range (up to $2877 \mathrm{~m}$ at PDM) but also of chemical species - the CO measurement being specific to PAES. It is devoted to photo-oxidant pollution at synoptic scale. PAES stations are away from any major source of pollution, and provide measurements (available on http://paes. aero.obs-mip.fr/) of ozone and gaseous precursors, $\mathrm{CO}$ and $\mathrm{NO}_{\mathrm{x} / \mathrm{y}}$, which are not yet systematically observed in France. Only ozone data from PAES will be considered in this study. 
The station altitudes range from 750 to $2877 \mathrm{~m}$. The Pic du Midi (PDM) is an isolated high summit in the Pyrenees; it is located $150 \mathrm{~km}$ to the east of the Atlantic Ocean and most of the time exposed to oceanic westerlies. This site is an interesting extension in south-western Europe of the network of high-moutain stations existing in the Alps. The Puy de Dôme (PDD) station is also an isolated summit in the Massif Central. The Donon tower (DON) in the Vosges Mountains emerges from a dense forest.

In order to view the new PAES network in the light of preexisting measurements at remote and high-altitudes sites in Europe, data from such sites have also been considered in our study. Some sites (e.g. Jungfraujoch, Zugspitze) even appear in many past studies, and have been included in the present study as well known references, in a concern of reliability.

Different Swiss organisations provided ozone data for 9 elevated stations. Time series from 4 sites in the Swiss Air Quality Network NABEL were investigated: Chaumont (CHA), Rigi-Seebodenalp (RIG), Davos (DAV) and Jungfraujoch (JUN). Data of Arosa (ARO), and Castaneda (CAST) were provided by the Swiss canton Graubünden; Zimmerwald (ZIM) by the Swiss canton Bern; finally, Zugerberg (ZUG) and Wengernalp (WEN) by the Institute for Applied Plant Biology. Some of the Swiss sites are described by Staehelin et al. (1994), Brönnimann et al. (2000) and Schuepbach et al. (2001).

We also used WDCGG hourly data for 7 additional stations, located in Germany ( $\mathrm{HOH}, \mathrm{SCH}$ and ZSP), Austria (SON), Italia (MTC) and Spain (NOI and SAN), the latter two in particular guarantee that the Pic du Midi does not lie at the edge, but in the bulk, of the considered station network.

Ozone data from the different ground stations were taken at various sampling rates (from $5 \mathrm{~min}$ to $1 \mathrm{~h}$ ) using standard UV absorption analysers. A coherent and synchronized dataset has thus been first obtained by averaging data from stations on a hourly basis. This hourly data set covers more than $80 \%$ of the 2001-2004 period for most stations, except Pic du Midi and Puy de Dôme for which the coverage rate is somewhat lower $(>65 \%)$ but remains acceptable. Data gaps do not exceed few days or weeks at most.

Other datasets used is this study are derived by averaging the hourly data on daily, monthly, 3-monthly, yearly or quadriennal time steps. Averages over long periods (3 months at least) are unaffected by the (much shorter) data gaps. Monthly means with underlying data coverage less than $60 \%$ were filtered out. Daily means were not filtered but as they are treated statistically, rare spurious values do not affect the global result.

\subsection{MOZAIC data}

The MOZAIC program was initiated in 1993 by European scientists, aircraft manufacturers and airlines to collect experimental data. Its goal is to help to understand the atmosphere and how it is changing under the influence of aircraft traffic and more widely of human activity (Marenco et al., 1998). MOZAIC consists of automatic and regular measurements of ozone and water vapour by five long range passenger airliners flying all over the world, with a sampling rate of $4 \mathrm{~s}$, i.e., approximately every $50-100 \mathrm{~m}$ along the vertical profiles. MOZAIC data provide, in particular, detailed ozone and water vapour climatologies in the troposphere and lowermost stratosphere since 1994 as well as $\mathrm{CO}$ and $\mathrm{NO}_{\mathrm{y}}$ since 2001. Details on the measurements performed by the MOZAIC program can be found in Marenco et al. (1998), Thouret et al. (1998) and Nédélec et al. (2003). Ozone measurements during MOZAIC ascent and descent vertical profiles over Frankfurt and Paris for the period January 2001December 2004 were used in the present study.

In the present study we consider MOZAIC ozone vertical profiles mainly over Frankfurt, but also Paris for a comparison. Those profiles are sampled during the ascent or descent phases of the aircrafts. For both airports MOZAIC take-offs and landings are rare in the evening, but occur mostly from the early morning to the early afternoon. This coincides more or less with the period between the daily minimum and maximum ozone content in the lowest levels. Therefore averaging all MOZAIC profiles available in a sufficiently long period will provide a result that is rather representative of a daily mean. For this reason no kind of diurnal adjustement was performed on the MOZAIC data.

The available profiles over Frankfurt amount to 3083 for the period 2001-2004. The MOZAIC flights are not uniformly distributed over the 12 months of a year. There are indeed about 25\% more MOZAIC flights in summer than in winter. In addition the frequency of MOZAIC flights is globally increasing from 2001 to 2004 . With a view to obtain a profile representive of the annual mean ozone profile over Frankfurt for the period 2001-2004, and to avoid overweighting the summer period, the available MOZAIC profiles were reduced to monthly mean profiles with corresponding standard deviation. The data were gridded on the vertical on a regular 50-m mesh, in asl coordinate. Thus we obtained 45 monthly mean profiles over Frankfurt airport over the 2001-2004 period (May 2002, December 2002, November 2004 are missing), with on average 64 profiles (at least 13) contributing to each monthly mean.

The same methodolgy was applied for Paris, but only 20 monthly mean profiles were obtained for 2001-2004, with on average 34 profiles (at least 12) contributing to each monthly mean.

Although the aircrafts fly rapidly away from/to the airport during their ascent/descent, the specific urban influence on the ozone profile above a Frankfurt is expected to increase the ozone gradient in the lowest levels due to enhanced fast titration by NO close to the surface and to vanish with elevation above the ground. For these reasons, we additionnally consider mean ozone profiles from balloon soundings at a rural site in Switzerland, Payerne. 


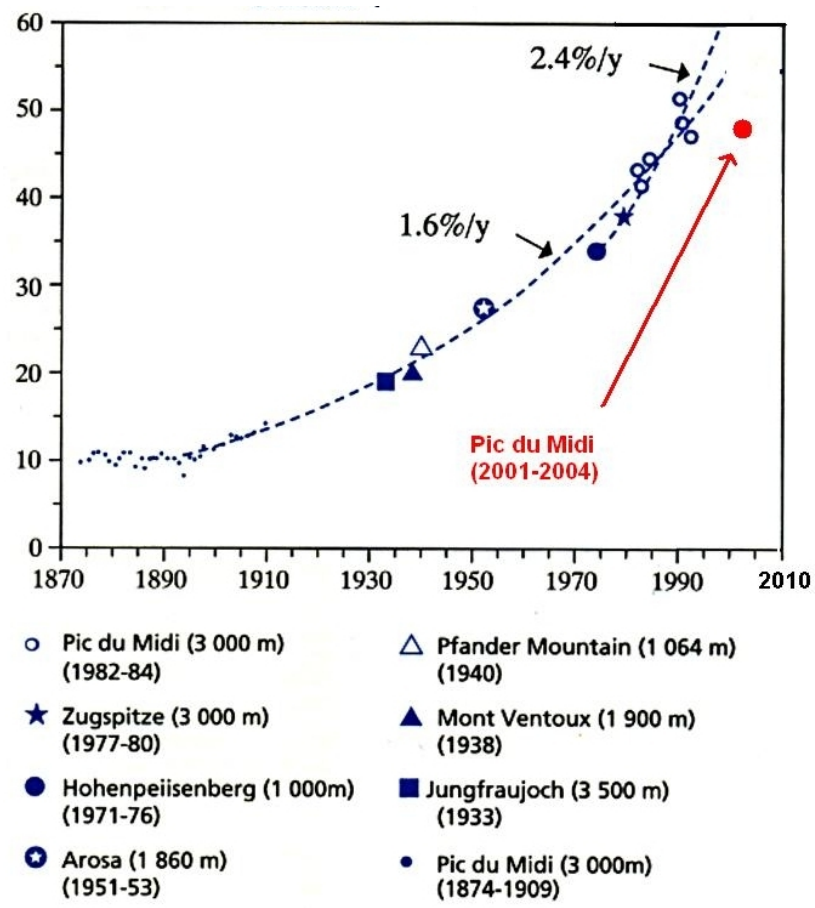

Fig. 2. Ozone evolution in the free troposphere over western Europe, extracted from Marenco et al. (1994), and completed with mean mixing-ratio at Pic du Midi (PDM) between 2001 and 2004.

\subsection{Balloon soundings}

Ozonesonde data from Payerne, Switzerland $\left(46.49^{\circ} \mathrm{N}\right.$, $6.57^{\circ} \mathrm{E}, 491 \mathrm{~m}$ a.s.l.) have been used in the altitude range $500-5000 \mathrm{~m}$ (from 950 to $550 \mathrm{hPa}$ ), with the aim to compare them to MOZAIC profiles and surface station stratification. Ozonesonde data were obtained from the World Ozone and Ultraviolet Data Centre (WOUDC). The vertical ozone profiles at 11 a.m. UTC are available for 2 or 3 days per week. Again no diurnal adjustement was performed on Payerne profiles because the launch time is approximately in the middle between the morning minimum and afternoon maximum ozone concentration in the boundary layer. So an average of the soundings is expected to be representative of the daily mean. Brewer-Mast and ECC sensors are used for the measurements of vertical distribution of ozone (respectively before and after August 2002). Total ozone measurements from Dobson spectrophotometers are used from Arosa (ARO, Switzerland) for the Payerne ballon series to derive the correction factors used to linearly scale the ozone profiles, as recommended in the World Meteorological Oragnization (WMO) standard procedure. We only used data for which the correction factor belong to the range $0.9-1.35$, as recommended by Logan (1994). More details on this ozonesonde data, measurements procedures, are given by Jeannet et al. (2007) and the references therein.

\section{Trends in tropospheric ozone}

Marenco et al. (1994) exploited ancient measurements at the Pic du Midi (PDM) station, and showed that the mean ozone concentration in the free troposphere has increased by a factor of 5 since the end of the 19th century, to reach between 47 and $48 \mathrm{ppb}$ in the early 1990s. This corresponds to a rate of $+1.6 \% \mathrm{yr}^{-1}$. However, $48.3 \mathrm{ppb}$ were observed on average at PDM between 2001 and 2004. Thus ozone mixing ratios at PDM seem to stabilize instead of increasing further at the rate proposed by Marenco et al. (1994), as seen in Fig. 2 . A comparable result can be stated for the Monte Cimone (MTC) station (Bonasoni et al. (2000) found $53 \pm 8.0 \mathrm{ppb}$ for the 1996-1998 period; concentrations are $52.8 \pm 9.0 \mathrm{ppb}$ over the 2001-2004 period).

This result at PDM can be put in wider perspective considering trends at other high-altitude sites in the Alps (JUN, ZSP and SON) over comparable periods. All the results are summarized in Table 2. Long and continuous data series from 1991 to 2004 exist for the above three stations. Trends and associated $95 \%$ confidence intervals have been calculated on the base of yearly mean values obtained from those data over different time periods: 1991-2004 (the complete data series); running decades starting in 1991, 1992, 1993, 1994 and 1995. Over the longest period (1991-2004), trends are significant and positive, especially for the highest station JUN $(0.62 \pm 0.23 \mathrm{ppb} / \mathrm{yr})$. However, a closer look at the decadal trends and their evolution in time shows a decrease in rate and statistical significance - even if they remain positive. There is hence some evidence that the increase of low tropospheric ozone in the Alpine area has slowed down since the early 1990 s, in agreement with the evolution observed at PDM or at MTC.

To assess the impact of the particular year 2003 (high ozone levels due to the summer heat-wave) on the calculated trends, we paid attention to whether the running decadal trends involve year 2003 or not. A noticeable impact is obtained for ZSP for the decade 1994-2003. The found rate $(+0.30 \pm 0.38 \mathrm{ppb} / \mathrm{yr})$ is higher than that for the 1993-2002 decade $(+0.22 \pm 0.32 \mathrm{ppb} / \mathrm{yr})$. However this result is the only exception to the rule of decreasing rates. This is explainable if one considers that 2003 being the last year of the decade, the high ozone value draws up the regression line at its endpoint. However this effect is not noticeable for JUN and SON (where decadal rates regularly decrease). Morevover the rate at ZSP almost vanishes for the decade 1995-2004 $(+0.03 \pm 0.39 \mathrm{ppb} / \mathrm{yr})$. So a minor impact of 2003 is found on trend calculations from data series exceeding 10 years.

More generally we also verified whether the interannual variability may affect the calculated trends. We estimated that variability to be the (square-rooted quadratic) mean departure of the yearly mean ozone levels from the linear regression curve. Considering the 1991-2004 period, we obtained 1.48, 1.47 and $1.39 \mathrm{ppb}$ for JUN, SON and ZSP, respectively. (Note that at the rates given in Table 2, 3-5 years 
Table 2. Trends and corresponding $95 \%$ confidence intervals (in ppb), of annual ozone means over the indicated periods at JUN, SON and ZSP.

\begin{tabular}{lllllll}
\hline & $1991-2000$ & $1992-2001$ & $1993-2002$ & $1994-2003$ & $1995-2004$ & $1991-2004$ \\
\hline JUN & $0.92 \pm 0.34$ & $0.68 \pm 0.38$ & $0.62 \pm 0.40$ & $0.54 \pm 0.36$ & $0.34 \pm 0.38$ & $0.62 \pm 0.23$ \\
SON & $0.46 \pm 0.36$ & $0.46 \pm 0.36$ & $0.40 \pm 0.39$ & $0.25 \pm 0.24$ & $0.12 \pm 0.34$ & $0.28 \pm 0.23$ \\
ZSP & $0.38 \pm 0.30$ & $0.29 \pm 0.33$ & $0.22 \pm 0.32$ & $0.30 \pm 0.38$ & $0.03 \pm 0.39$ & $0.27 \pm 0.22$ \\
\hline
\end{tabular}

are needed for ozone trends to emerge from the interannual "noise"). For each station, years with ozone mean level departing (positively or negatively) from the trend curve by more than the calculated variability have been excluded for a new trend calculation (in particular year 2003 is filtered out in this way). The obtained results (not shown) turn out to be very comparable to those found without filtering.

The trends in Table 2 are consistent with those by Ordóñez (2006) based on data from 8 sites in the Central Alps (Germany, Switzerland and Austria), 3 of them above $2000 \mathrm{~m}$ (including JUN, SON and ZSP) and 5 between 1000 and $2000 \mathrm{~m}$ (including ARO, DAV, RIG and CHA). For these stations, they found an average increase of $0.5 \mathrm{ppb} \mathrm{yr}^{-1}$ between 1992 and 2002 (except in summer).

Those trends based on surface data (increase by $0.5,0.5$ and $1.2 \% / y r$ for ZSP, SON and JUN, resp., as derived from Table 2) are also consistent with those proposed by Zbinden et al. (2006) based on MOZAIC data. They showed for the trends of integrated tropospheric ozone column over the period 1995-2001 a linear increase by $0.7 \% \mathrm{yr}^{-1}$ above Frankfurt and $0.9 \% \mathrm{yr}^{-1}$ above Paris. This motivated the comparisons between surface data and MOZAIC profiles made in this study (see Sect. 4).

In summary, ozone mixing ratios appear to go on increasing in the troposphere over Western Europe, but the ozone evolution does not seem to follow any longer the rapid trend proposed 12 years ago by Marenco et al. (1994). In addition, for some stations such as PDM, no trend is found since the 1990s, and for stations of comparable altitude in the Alps (SON and ZSP), the positive trend is no longer statistically significant. This contrasts with the rapid increase between the 1980s and the 1990s. This is probably due to the significant decrease of ozone precursors emissions in Europe since the late 1980s. Researching the causes of this evolution however would imply considering trends season by season because of varying influence of the boundary layer at mountain sites. It was discussed in detail by Ordóñez (2006) and Zbinden et al. (2006). Finally, it should be noted that the trend established by Marenco et al. (1994) is based on ozone mixing ratios of stations of very different altitude, and therefore should be interpreted with caution. Indeed ozone level and variability strongly depend on altitude in the lower troposphere. This is considered in detail in the next section.

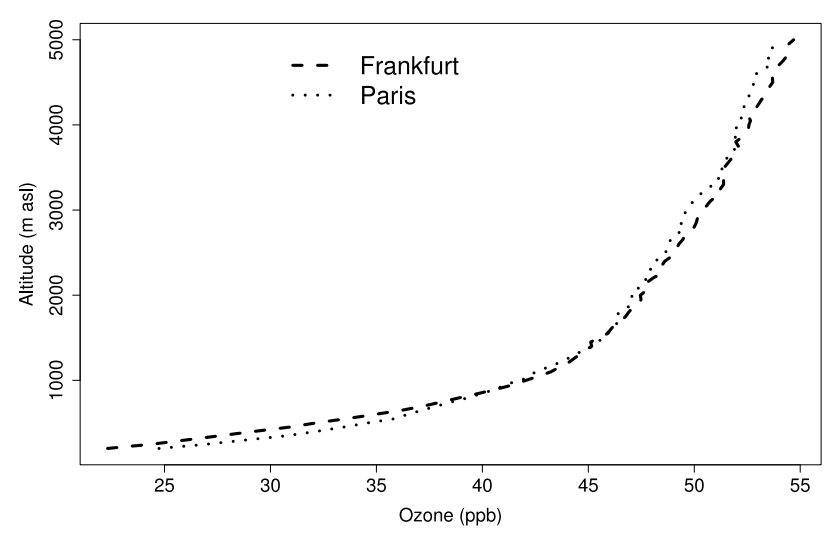

Fig. 3. Comparison between MOZAIC mean ozone profiles above Paris and Frankfurt over the period January 2001-July 2004 (see text for details on the calculation).

\section{Influence of altitude on ozone levels and variability}

\subsection{Background levels and variability}

The mean ozone concentration is known to strongly increase with altitude in the first kilometres of the troposphere (e.g., Brönnimann et al., 2000; Zaveri et al., 1995). Near the ground, ozone depletion is mainly due to surface deposition and fast titration by species emitted from the surface. It is thus of primary importance to quantify this stratification when considering data from mountain stations at different altitudes. Therefore, we propose a comparison of the ozone levels as a function of altitude between a set of surface stations vertically distributed in the first $4 \mathrm{~km}$ of the troposphere, and climatologies of MOZAIC vertical profiles and balloon soundings.

Prior to this, Fig. 3 overlays mean ozone profiles from MOZAIC above Frankfurt and Paris, in order to check whether it makes sense to compare ozone background levels from sites distant of several hundred kilometres from each other (and subsequently to compare surface data in France, Switzerland, etc., to MOZAIC data in Frankfurt and sounding data in Payerne). Those profiles were produced by averaging together the monthly mean profiles simultaneously available over Paris and Frankfurt in the period January 2001-December 2004. For Paris the data coverage is by far 
(a)

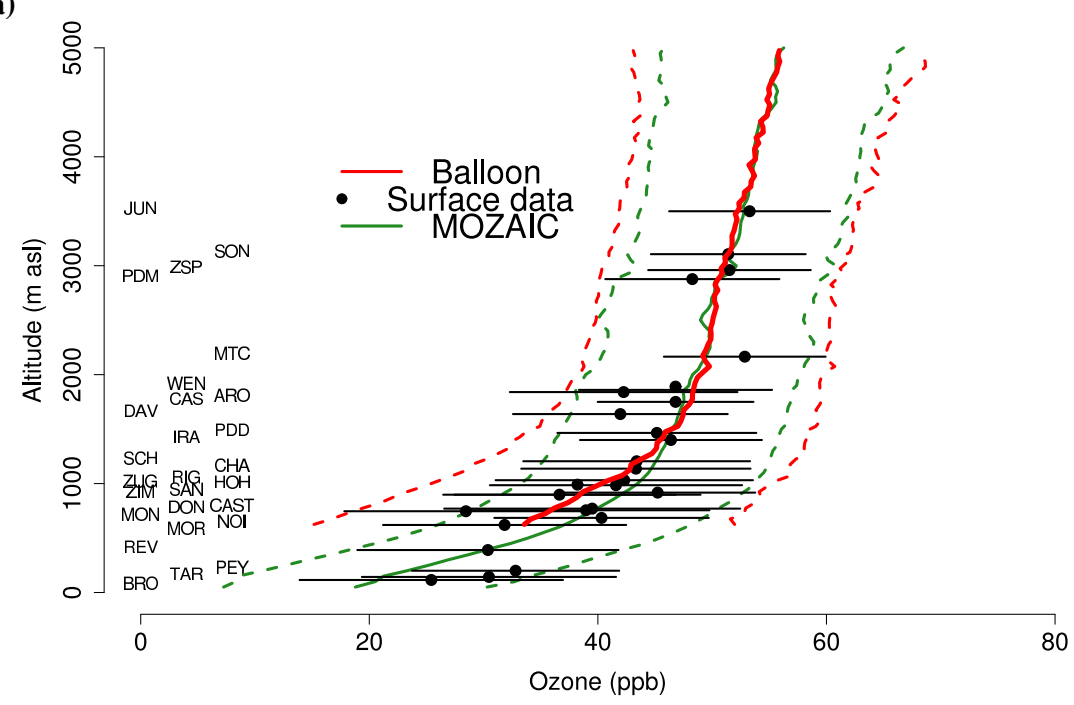

(b)

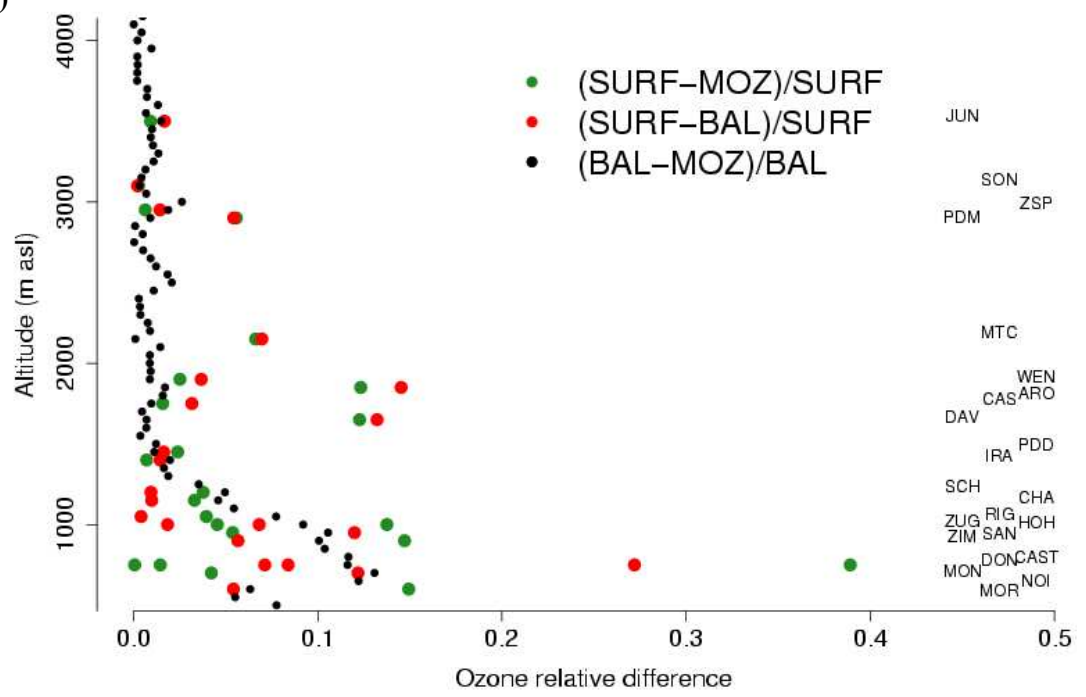

Fig. 4. (a) Mean ozone profiles over the period January 2001-December 2004, from MOZAIC data over Frankfurt (green plain curve), balloon soundings over Payerne (red plain curve) and data from surface stations (black dots), and related \pm 1 standard deviation (green and red dashed curves and bars, respectively. (See the text for the details of the calculations.) (b) Relative departure (in absolute value) between the ozone mean concentration from the three datasets.

not as good as for Frankfurt (see Sect. 2.2). Thus Fig. 3 only includes 24 monthly mean profiles (out of 45 available over Frankfurt). (No care was taken here on the distribution of the 24 months with respect to the seasonal cycle, because the profiles in Fig. 3 do not aim at any kind of climatological representativity). Both profiles are very similar to each other. This justifies that it makes sense to compare ozone background levels from sites distant of several hundred kilometres from each other. Hence a direct comparison can be done between Frankfurt and Payerne mean profiles, and mean ozone concentrations from the vertically ranged surface stations.

Figure 4a shows statistics over the period January 2001December 2004 for the ozone concentration in the low tro- posphere and its variability. The 2001-2004 mean MOZAIC ozone profile above Frankfurt was produced by averaging together the available 45 monthly-mean profiles. In this way the obtained profile can hence be considered with some confidence to be representive of the annual mean ozone profile over Frankfurt for 2001-2004. The variability interval also results from averaging the 45 monthly standard deviations. The Payerne profile is an average of all available soundings that were regularly launched twice per week around 11:00 UTC during the 2001-2004 period. The variability interval is the associated standard deviation. Regarding finally the surface stations, the 2001-2004 averages and associated standard deviations were performed on the base of the hourly 
(a)

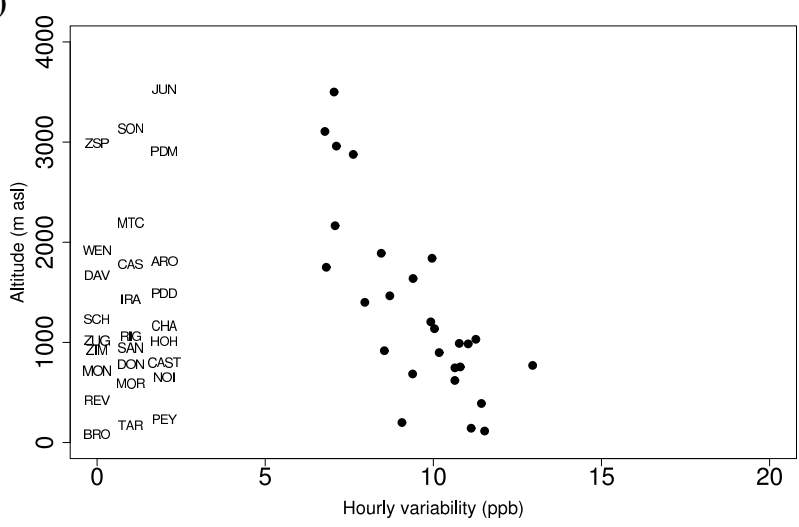

(b)

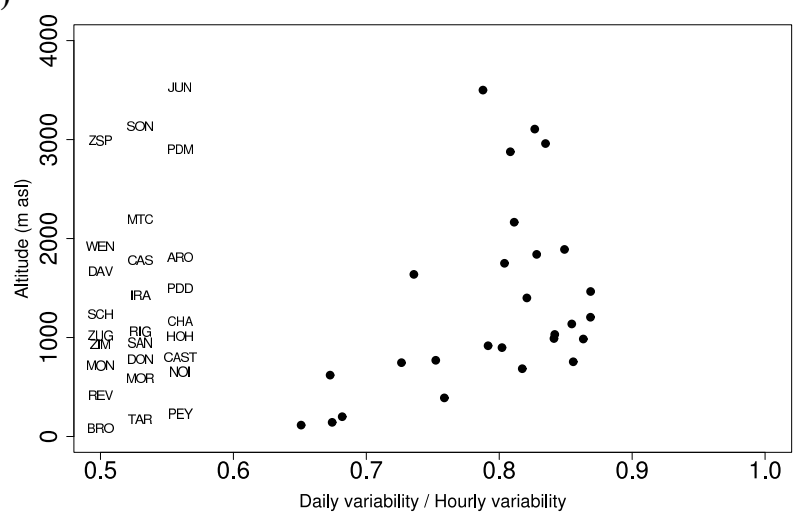

Fig. 5. (a) Variability (standard deviation) of hourly surface ozone data during the period 2001-2004. (b) Ratio of daily variability to hourly variability.

dataset. Figure $4 \mathrm{~b}$ shows how much the mean concentrations in Fig. $4 \mathrm{a}$ from the three data sets (MOZAIC profiles, Payerne soundings and surface stations) depart from each other, in order to assess more quantitatively how representative they are of a background ozone profile in the low troposphere over Western Europe. Comments on the Fig. 4 are given below in terms of (i) ozone concentration and (ii) vertical gradient.

(i) The agreement between MOZAIC profiles and Payerne soundings is excellent (deviation $<2 \%$ ) above about $1200 \mathrm{~m}$ a.s.l. (this was expected given the good agreement between Frankfurt and Paris in Fig. 3). Below, the Payerne profile shows a negative bias (of about $5 \mathrm{ppb}$ ) with respect to MOZAIC. As a result mean ozone levels depart from each other up to $15 \%$ in the lowermost levels ${ }^{1}$. The transition around $1200 \mathrm{~m}$ between good (deviation $<2 \%$ ) and poorer (deviation $>10 \%$ ) agreement is strikingly sharp. As a conclusion, either Frankfurt or Payerne data above 1200 m can be taken as free tropospheric reference for the surface stations.

Focusing now on the stations, their annual mean ozone levels depart less than $15 \%$ from the free-tropospheric reference profiles above $1000 \mathrm{~m}$, and less than $8 \%$ above $2000 \mathrm{~m}$. Again, a sharp transition is found around the less-than-15\% limit, with quite large disagreement below (up to $40 \%$ ), likely

\footnotetext{
${ }^{1}$ To explain that, two arguments can be invoked: (i) the Payerne site is at $491 \mathrm{~m}$ a.s.1., i.e. about $400 \mathrm{~m}$ higher than Frankfurt airport. If focusing on the influence of surface emissions on ozone in the lowest levels, the agl vertical coordinate would be more appropriate to compare ozone profiles. Shifting downwards the Payerne profile of about $400 \mathrm{~m}$ indeed provides a much better agreement for the lowest levels. (ii) Payerne is located just between the Alps and Jura mountain ridges. There a cold-air basin forms frequently in winter under anticyclonic conditions. The very stable air stratification in the levels below the Jura crest (1300-1500 m a.s.1.) might lead to relatively important $\mathrm{NO}_{\mathrm{x}}$ concentrations even at this rural site. Low temperature and radiation (stratus layer) do not favour photochemical ozone production but rather destruction.
}

caused by specific surface effects at each site. It is difficult to say whether the low altitude surface stations agree better with Frankfurt or Payerne profiles. Consequently, surface stations devoted to the monitoring of background low-tropospheric ozone should be settled in any case above 1000-1200 m, and if possible above $2000 \mathrm{~m}$.

(ii) Averaged ozone level strongly depends on altitude and varies from 25 to $53 \mathrm{ppb}$ over the range $100-3500 \mathrm{~m}$. A change in ozone vertical gradient is clearly visible in Fig. 4a around $1000-1200 \mathrm{~m}$. This is an indication of how deep is the direct influence of surface deposition and boundary-layer chemistry on the ozone level. The ozone gradient from the MOZAIC profile is very steep from the ground up to $1000 \mathrm{~m}$, of about $30 \mathrm{ppb} / \mathrm{km}$. The Payerne profile shows a comparable gradient (despite the $400 \mathrm{~m}$ shift in height). Since the Frankfurt and Payerne profiles agree very well with each other above $1200 \mathrm{~m}$, the common value $3 \mathrm{ppb} / \mathrm{km}$ can be given for the gradient. No quantitative estimation of ozone gradients from the stations may reasonably be given, but a striking result is nevertheless that also a set of surface stations at different elevations is able to capture this transition in ozone mean stratification, despite the fact that each surface station, even at high altitude, is intrinsically under the influence of the surface.

To further investigate this point, we consider ozone variability (standard deviation) as a function of station elevation, on the base of a comparison between hourly and daily data. With the second dataset (daily data) the component of the diurnal photochemical cycle of ozone is indeed filtered out from the calculated variability. So the comparison of both results allows to discriminate boundary-layer photochemistry from the other sources of variability. Results are displayed in Fig. 5. Variability based on hourly data (Fig. 5a) is maximum at sea level $(10 \mathrm{ppb})$ and decreases with height to reach about $5 \mathrm{ppb}$ at the highest station. (Note that this decrease is opposite to the increase of ozone mean level, so it is even more 
(a)

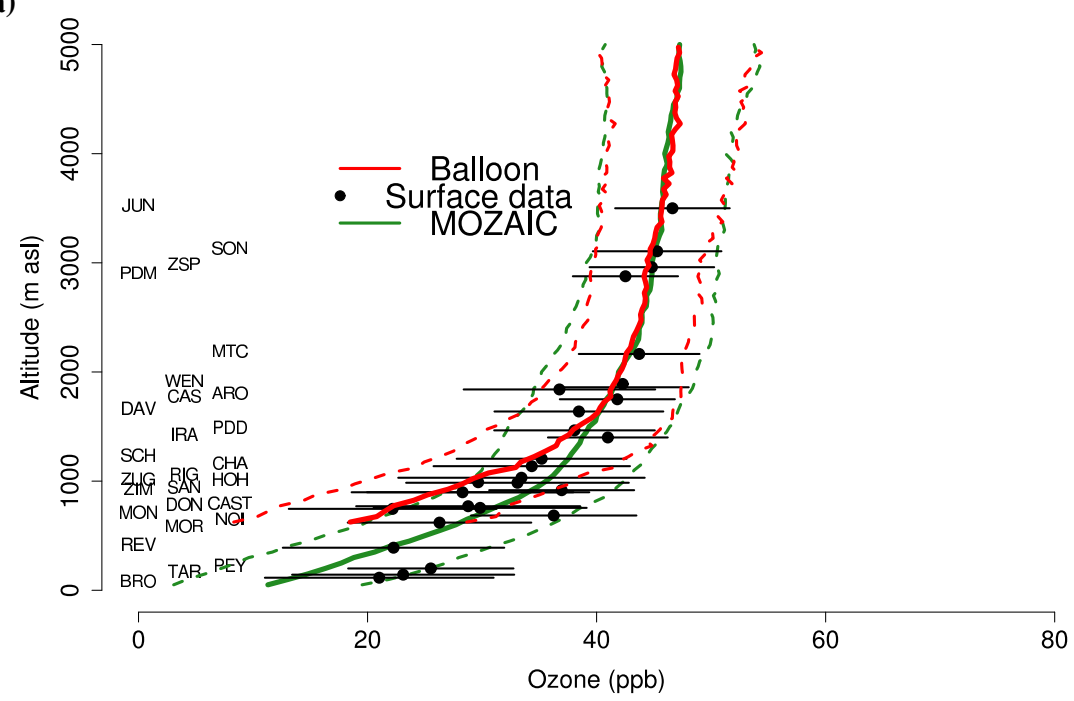

(b)

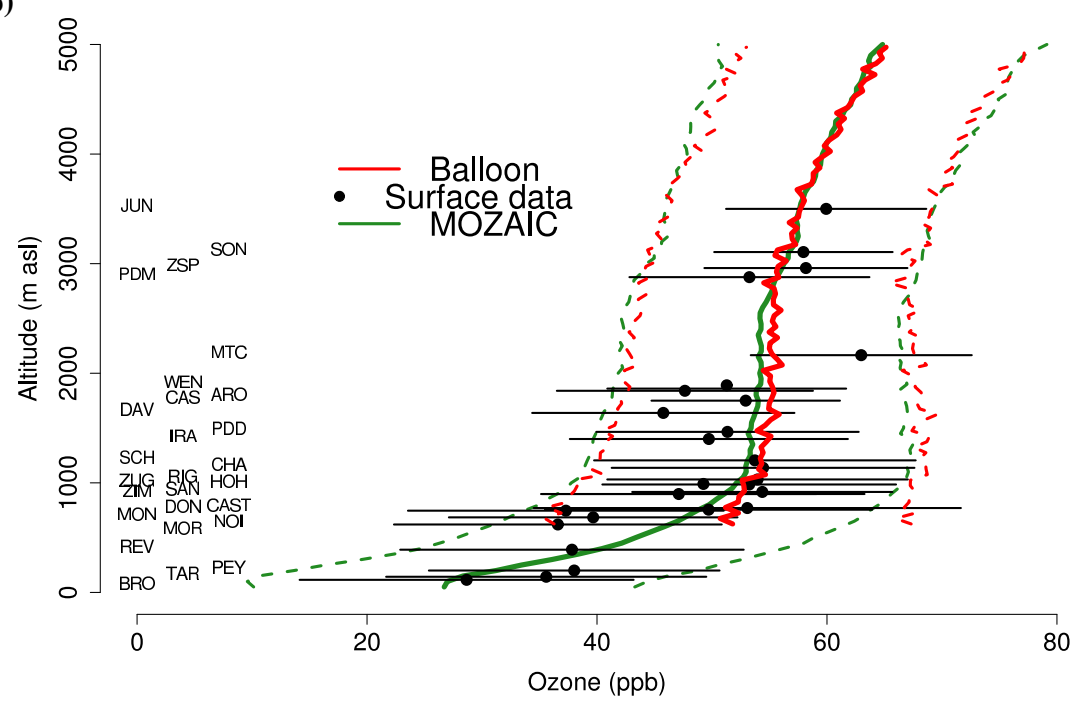

Fig. 6. As Fig. 4 for (a) winter (DJF) and (b) summer (JJA).

pronounced in relative value - not shown). This result is not surprising because ozone is strongly affected by surface effects and boundary-layer photochemistry. The role of the latter in the variability compared to the contribution of dayto-day changes in ozone level (due to changing weather conditions, transport at synoptic scale, etc.) is made evident considering the ratio daily variability/hourly variability (Fig. 5b). The ratio is in the range $80-90 \%$ for stations above $1000 \mathrm{~m}$ but drops to only $60-70 \%$ below; it means that diurnal photochemistry takes a considerable part - about the third - of the total variability for stations below $1000 \mathrm{~m}$ and less and less above, where the day-to-day changes account for 80-90\% of the variability. Thus the altitude $1000 \mathrm{~m}$ asl appears to mark a clear transition from a boundary-layer to a free-tropopheric regime for ozone (at least as observed by surface stations). This is moreover consistent with the change in slope of ozone stratification noted above.
To summarize it can be stated that altitude is a key parameter for surface observation of both mean level and variability of ozone mixing ratio. Ozone mean level is indeed a highly stratified field in the lower troposphere. Hence, estimations of the long term trends should be only done using data from the same site, or at least from sites of comparable altitudes. Photochemistry appears to be the major source of variability in the lowest kilometre. Day-to-day variability peaks around $1000 \mathrm{~m}$. As the influence of photochemistry and surface deposition is very dependent on the measurement site, only high-altitude stations (possibly above $2000 \mathrm{~m}$ ) are reasonably representative of the background tropospheric ozone at their altitude. Seasonal aspects of ozone variability are considered in more detail in the following paragraph. 
(a)

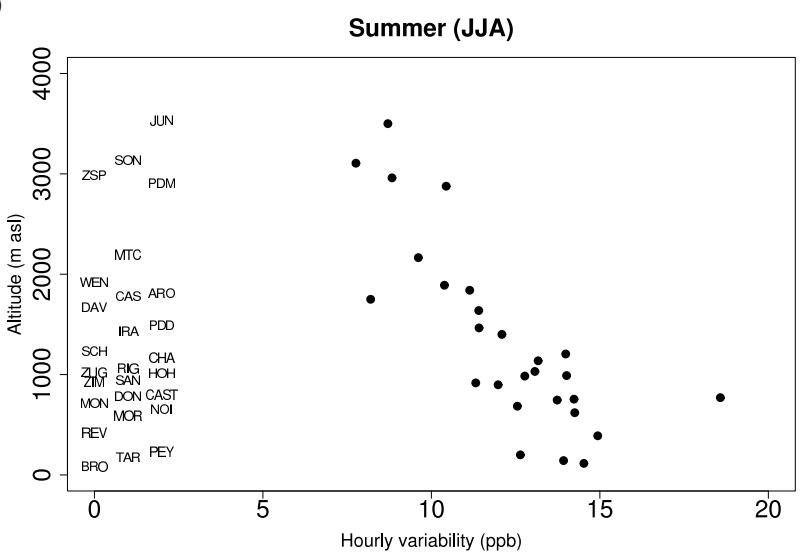

(c)

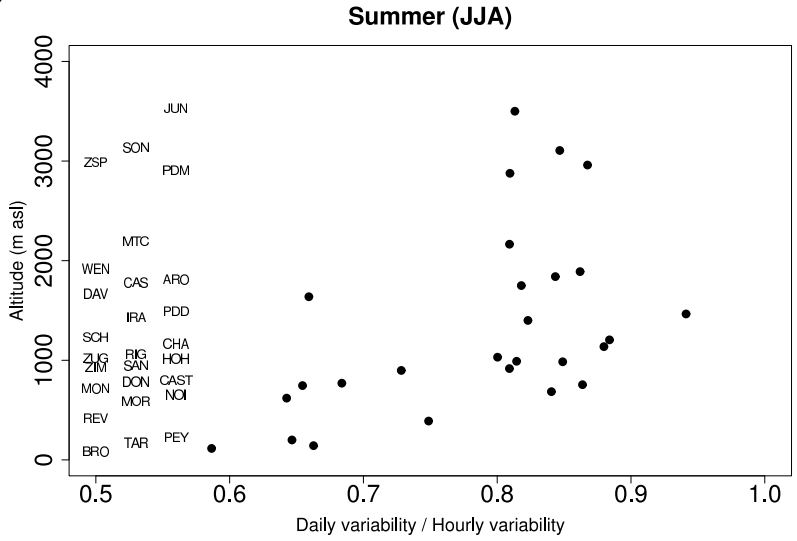

(b)

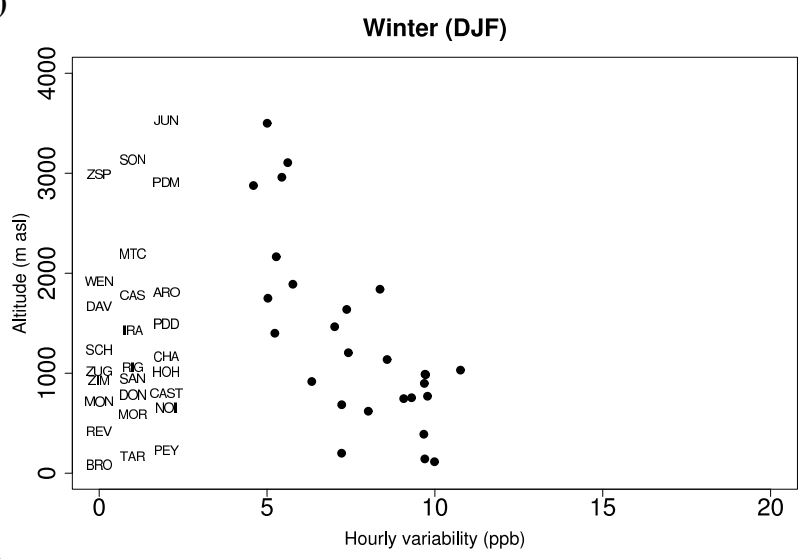

(d)

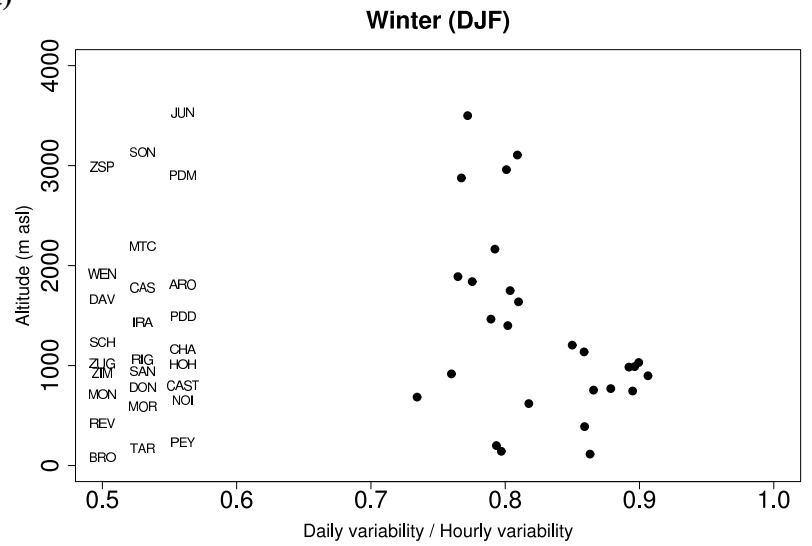

Fig. 7. Variability (standard deviation) of hourly surface ozone data during the period 2001-2004 for (a) summer and (b) winter. Ratio of daily variability to hourly variability for (c) summer and (d) winter.

\subsection{Seasonal aspects}

Figure 6 is similar to Fig. 4 a but winter and summer are distinguished. It clearly shows $10 \mathrm{ppb}$ higher ozone values in summer than in winter. The three datasets also show that during summer, the variability is also almost twice as important as during winter, likely because of enhanced photochemistry $^{2}$. A result from Fig. 5 (diurnal photochemistry contributing to about the third of the total variability in the lowest kilometre) is supported by a similar figure distinguishing winter and summer (Fig. 7): in winter, when photochemistry is not very active, the day to day changes account for exemple for $75-90 \%$ of the variability at all levels. In summer,

\footnotetext{
${ }^{2}$ However no quantitative comparison of variabilities from MOZAIC or balloon data and from surface stations can be given. Even if the amount of MOZAIC or balloon profiles is enough to provide representative mean values, their distribution within the day is too sparse (few profiles per day and at varying hours for MOZAIC, profiles and soundings at 11 every 2-3 days for Payerne) to allow a rigorous comparison of their standard deviation to that from hourly data.
}

the part of the variability due to diurnal photochemistry is important only in the first kilometre.

A more detailed seasonal analysis is given now in term of ozone concentrations and variability. The yearly evolution of the monthly-averaged ozone mixing ratios was analysed for the 4 years (Fig. 8). It shows a systematic seasonal variation with minimum values between 10 and $45 \mathrm{ppb}$ in autumnwinter (November-January) from the lowest to the highest station. The first maximum values (between 30 and $70 \mathrm{ppb}$ according to the elevation of the station) are systematically observed during late spring and correspond to the spring tropospheric ozone maximum well documented in the literature (Monks, 2000; Vingarzan, 2004). Depending on the years and also on the stations, between one and three additional maxima in ozone values may be observed during summer and early autumn according to the variable occurrence of lasting anticyclonic episodes and heatwaves. Such episodes can be evidenced by meteorological observations at PDD (Fig. 9). Each can be linked to ozone peaks at low- or midaltitude stations and even at high altitude stations in some case in Fig. 8 (episodes marked with arrows). Ozone levels of some mid-altitude stations (between 700 and $1400 \mathrm{~m}$ ) thus 


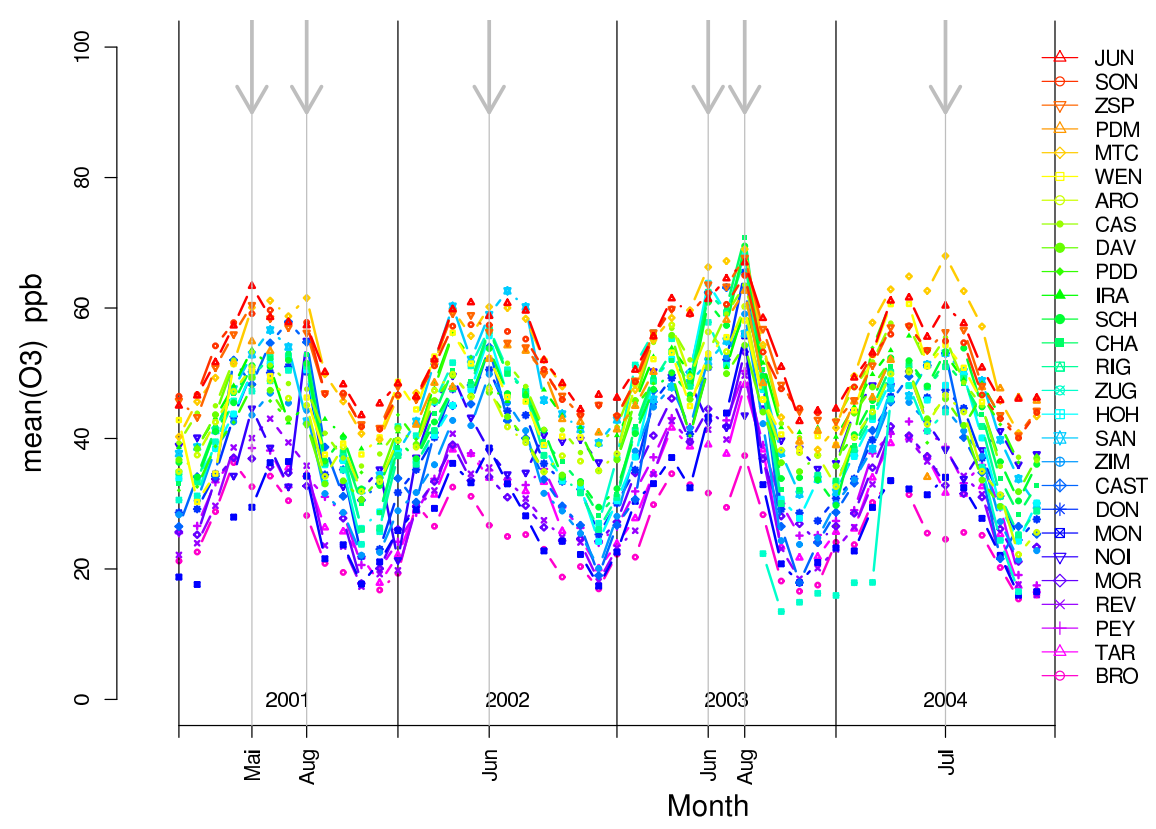

Fig. 8. Monthly averaged ozone mixing ratios (ppb) for all stations (sorted and colored by growing altitude). Arrows: see explanation in Fig. 9.

may sometimes exceed ozone levels at the highest stations (e.g., during the extremely warm and dry summer of 2003). Summer photochemical episodes following the spring (tropospheric) maximum induce a more or less constant ozone level from April to September known in the literature as the broad summer maximum (e.g., Ribas and Peñuelas, 2004). Note however that summer pollution episodes occur at local, or at most regional, scale whereas the spring maximum is a hemispheric phenomenon.

The variability associated to seasonal (3-month) statistics on ozone for the 4 years is displayed in Fig. 10. For clarity mean seasonal ozone levels and relative variability based on daily data are represented only for two distinct groups of stations: below $500 \mathrm{~m}$ and above $2800 \mathrm{~m}$ (the stations inbetween - not shown - have intermediary behaviors). The seasonal cycle of relative variability (ratio of standard deviation to mean level) is quite different for the two groups: at low altitude variability is maximum in winter and minimum in spring; at high altitude, variability is maximum in summer and minimum in winter.

The winter maximum of (relative) variability at low altitude can be explained by low mean levels and at the same time variable deposition and destruction that occur in the boundary layer and cause enhanced variability (e.g., Ordóñez et al., 2005). Contrariwise the high altitude stations are decoupled from the boundary layer and sample mostly free-tropospheric air, which explains low variability (even in relative value).
Relative variability at high altitude reaches its maximum in summer (despite high ozone level). At low altitude it is not as high as winter (it is in fact higher in absolute value - not shown - especially for the "photochemical" summers 2001 and 2003) but however higher than in spring and autumn. Thus variability appears to be enhanced at all levels in summer. Possible reasons for larger ozone variability at $2-3 \mathrm{~km}$ height during summer are manifold. The planetary boundary layer can reach altitudes of 2 to $3 \mathrm{~km}$ during summer, especially during photochemical ozone production episodes related to large surface temperatures (e.g. Vautard et al., 2005, for the summer 2003 heat wave). Moreover, the day-to-day net photochemical production in the boundary layer during lasting pollution episodes may be exported into the free troposphere. Finally, vertical stratification of free tropospheric ozone is generally enhanced during summer in midlatitudes, due to less vigorous vertical mixing during summer related to smaller vertical wind shears (e.g., Beekmann et al., 1997; Colette et al., 2005; Colette and Ancellet, 2005).

Finally the spring variability is at all altitudes lower than the summer variability while ozone levels are comparable (broad summer maximum). (There was a notable exception in 2002 when summer variability was especially low for some stations due to particularly bad weather and weak photochemistry). Low variability has to be linked to the hemispheric scale of the ozone spring maximum.

To summarize the most commonly observed annual evolution of background ozone level is a first maximum in spring (April-May) linked to the increase of tropospheric ozone at 

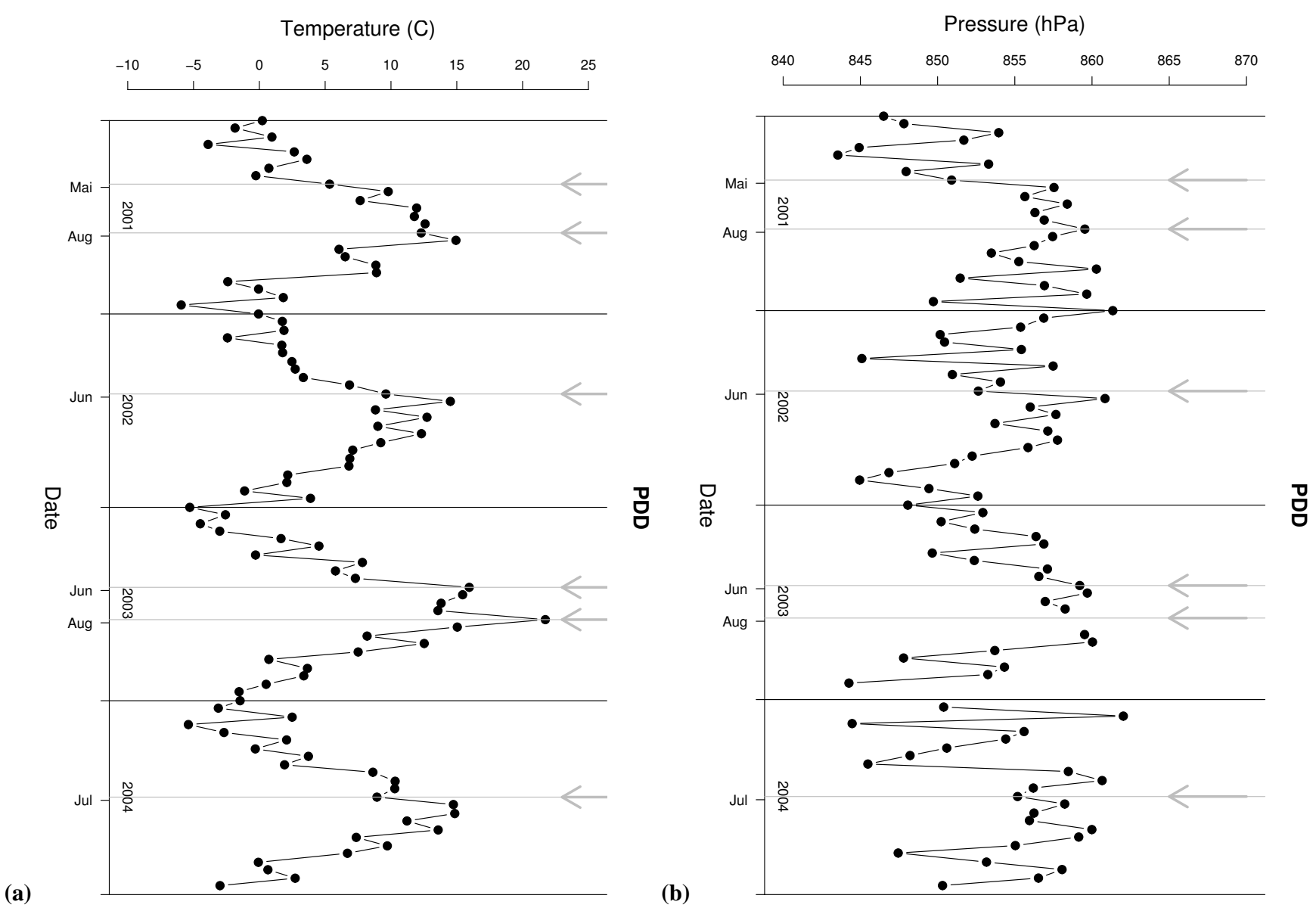

Fig. 9. 15 day-average temperature (a) and pressure (b) at PDD between 2001 and 2004. Arrows indicate the occurrence of lasting anticyclonic episodes and accompanying heat-waves.

the hemispheric scale, followed by a second one in summer when persistent anticyclonic weather allows enhanced photochemical production in the low levels. The summer maximum is associated with larger variability than the spring maximum, indicating the local or at most regional character of the phenomenon and its link to rapid photochemistry. This result is also valid for the highest stations and hence is an indication that the boundary layer photochemical-production in summer is susceptible to affect the composition of the lower free troposphere for sufficiently lasting episodes.

\section{Conclusions}

The present study - an analysis of ozone data over 4 years (2001-2004) from 27 surface stations in France, Switzerland, Germany, Austria, Italy and Spain - has been the first opportunity to put original databases from two French networks, MERA and PAES, in a European perspective including more widely known sites for ozone measurements (e.g., Jungfraujoch, Zugspitze) as well as airborne MOZAIC data and ozone soundings above Payerne (Switzerland). The considered set of stations covers a range of altitudes between 115 and $3580 \mathrm{~m}$ and therefore allows to improve our knowledge on the vertical distribution of ozone in the lower troposphere.

Decadal trends in mean tropospheric ozone level were first discussed. The most recent series of measurements (20012004) at the French station Pic-du-Midi (2877 m) does not show any evolution since the early 1990s, and therefore does not continue the rapid increase observed during the 1980s. The ozone measurements at Monte Cimone (northern Apennines, Italy) support this finding. For some stations in the Alps comparable to Pic du Midi (namely, Jungfraujoch, Sonnblick and Zugspitze) the trends found over running decades starting from 1991 to 1995 , are positive but decreasing and less and less statistically significant.

The main focus of the study was on the vertical distribution of ozone mixing-ratio and variability in the lower troposphere. The 2001-2004 mean ozone profiles over Frankfurt and Payerne depart less than 2\% from each other above $1200 \mathrm{~m}$ a.s.l. Below the latter threshold altitude, the 


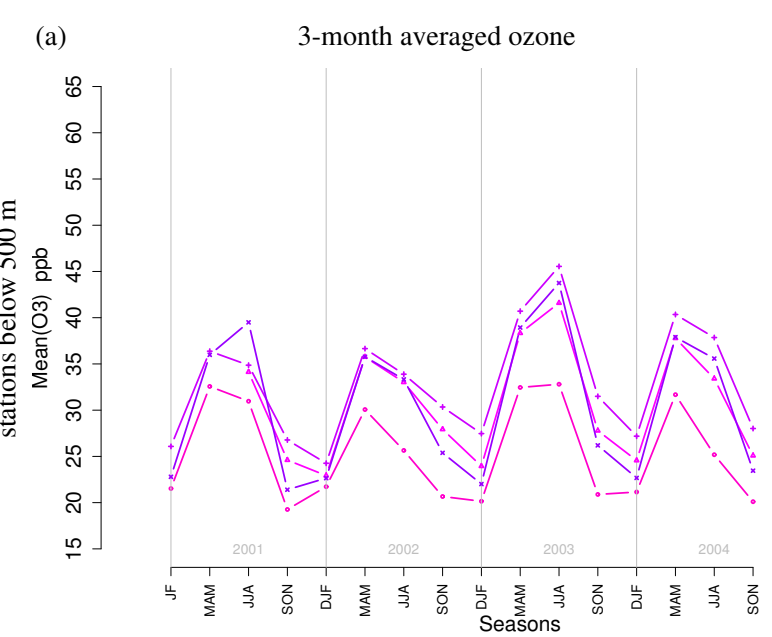

(c)

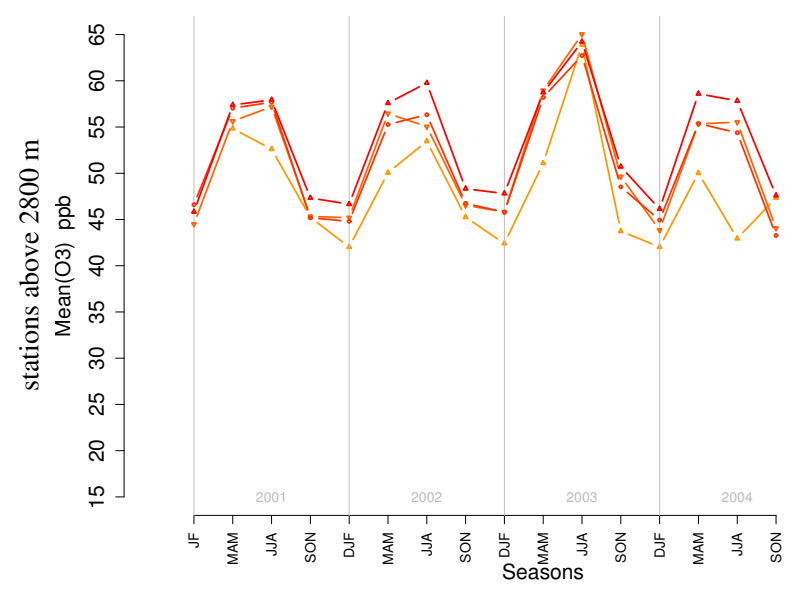

(b)

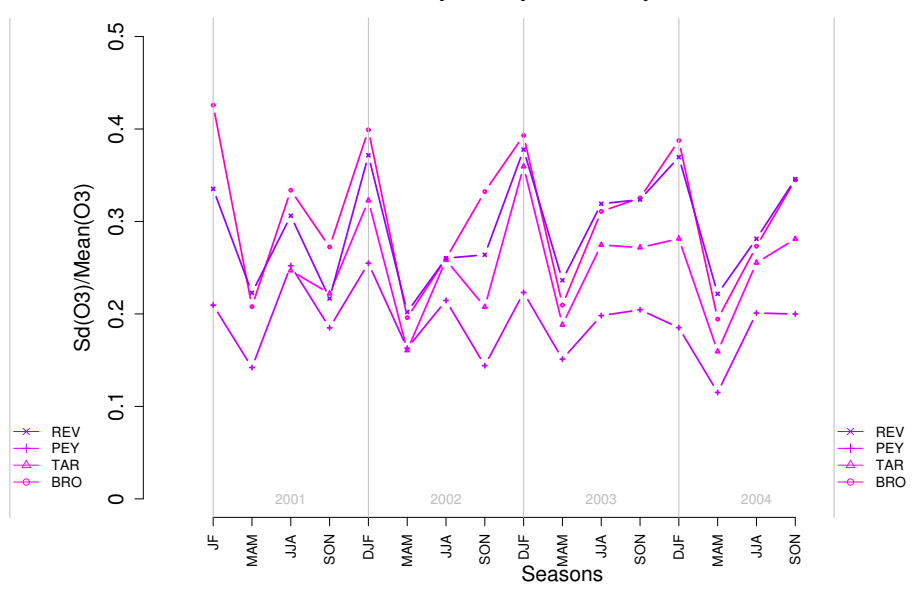

(d)

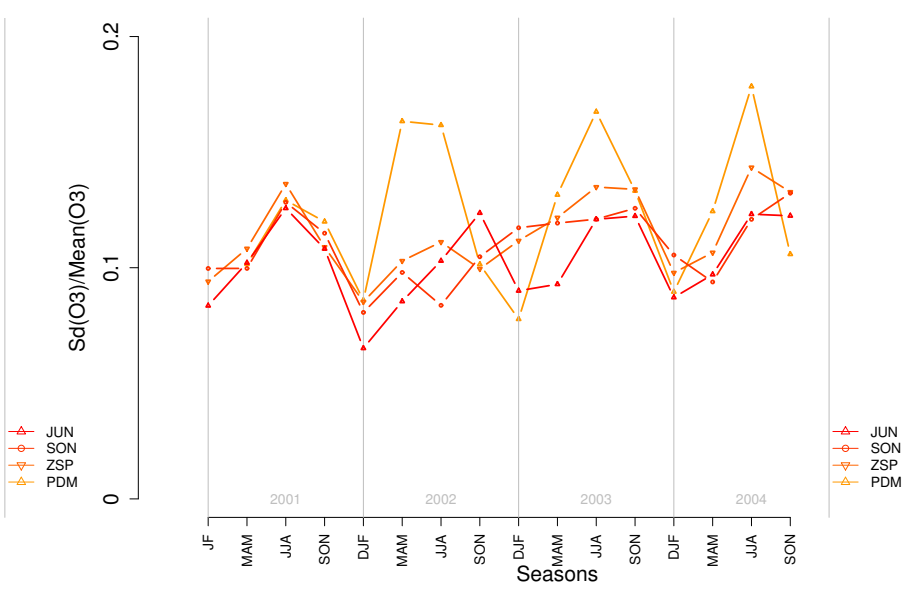

Fig. 10. (a) Seasonal (3-month) averaged ozone mixing ratio and (b) relative day-to-day variability (i.e., standard deviation based on the daily data divided by seasonal mixing ratio) for stations below $500 \mathrm{~m}$. (c, d) as (a, b) but for stations above $2800 \mathrm{~m}$.

agreement is poorer $(15 \%)$ due to surface effects. Those profiles are characterized by a sharp positive gradient in the first kilometre, a transition layer around 1000-1200 m, and a slower increase above (about $3 \mathrm{ppb} / \mathrm{km}$ ). This points out that ozone mixing-ratio is a highly stratified field in the lower troposphere. Therefore for the interpretation of ozone surface data, the altitude of the considered station and the possible role of rapid vertical transport should be considered as key elements.

The mean ozone levels at the highest surface stations appear to follow rather closely the mean vertical profile given by MOZAIC or the balloon soundings. In particular, the stations above $2000 \mathrm{~m}$ a.s.l. provide mean ozone levels that depart less than $8 \%$ from the MOZAIC free-tropospheric reference. The departure between 1200 and $2000 \mathrm{~m}$ is less than $15 \%$. Again the altitude $1200 \mathrm{~m}$ turns out to be a threshold. Below, specific surface effects become predominant and the disagreement can be as high as $40 \%$. Consequently, surface stations devoted to the monitoring of background free-tropospheric ozone should be settled if possible above $2000 \mathrm{~m}$ a.s.l.

Investigation of ozone variability as a function of altitude confirms that levels around $1000 \mathrm{~m}$ mark a rather clear transition between boundary-layer and free-tropospheric regimes for ozone, especially in summer when photochemistry accounts for about the third of the variability in the lowest kilometre, but only less than $20 \%$ above, where day-to-day changing weather conditions (and perhaps also transport of ozone at the synoptic scale) cause most of ozone variability.

Nevertheless the photochemical production in the boundary layer remains detectable at high-altitude sites during sufficiently lasting pollution episodes at the regional scale - in general in summer. Such episodes influence ozone monthly means at all altitudes. Maxima may appear for summer months (June to September) in addition to the spring tropospheric maximum (April-May). As a result the ozone level 
remains more or less constant and high in spring and summer - what is known as the broad summer maximum. A complementary and newer result concerns variability, that is clearly higher (even in relative value) during summer than in spring. This confirms that spring and summer maxima have causes of different natures and at different scales. Downscaling in time, one above mentioned result was the strong dependence of ozone sub-daily variability on station altitude. This opens the question of the diurnal variation of ozone observed at various altitudes, that will be addressed in detail in a coming paper.

Acknowledgements. We thank the numerous measurement programs, institutions and people for careful work done in obtaining the data used in this study (see Table 1). We are particularly grateful to the following people for providing us the data: W. Spangl from the Federal Environmental Agency of Austria; G. Nejedly and H. Lötscher, from the Swiss cantons Bern and Grison, respectively; H. E. Scheel from the Institute for Meteorology and Climate Research (Germany, Forschungszentrum Karlsruhe); S. Braun from the Institute for Applied Plant biology (IAP); for NABEL: R. Weber from the Swiss Federal Office for the Environment (FOEN), C. Hüglin from the EMPA and M. Stucki. We thank R. Stübi (Meteoswiss) for his interesting hints to interpret the Payerne profiles. MERA and PAES are funded by the French agency for environnement and energy control ADEME and the National Institute for Universe Sciences (INSU).

Edited by: R. Vautard

\section{References}

Beekmann, M., Ancellet, G., Blonsky, S., Muer, D. D., Ebel, A., Elbern, H., Hendricks, J., Kowol, J., Mancier, C., Sladkovic, R., Smith, H., Speth, P., Trickl, T., and Haver, P. V.: Regional and global fold occurences and related cross tropopause ozone flux, J. Atmos. Chem., 28, 29-44, 1997.

Bonasoni, P., Stohl, A., Cristofanelli, P., Calzolari, F., Colombo, T., and Evangelisti, F.: Background ozone variations at Mt. Cimone Station, Atmos. Environ., 34, 5183-5189, 2000.

Brönnimann, S., Schuepbach, E., Zanis, P., Buchmann, B., and Wanner, H.: A climatology of regional background ozone at different elevations in Switzerland (1992-1998), Atmos. Environ., 34(29-30), 5191-5198, 2000.

Brönnimann, S., Buchmann, B., and Wanner, H.: Trends in nearsurface ozone concentrations in Switzerland: the 1990s, Atmos. Environ., 36(17), 2841-2852, 2002.

Brunekreef, B. and Holgate, S.: Air pollution and health, Lancet, 360(9341), 1233-1242, 2002.

Carslaw, D.: On the changing seasonal cycles and trends of ozone at Mace Head, Ireland, Atmos. Chem. Phys., 5, 3441-3450, 2005, http://www.atmos-chem-phys.net/5/3441/2005/.

Colette, A. and Ancellet, G.: Impact of vertical transport processes on the vertical layering of tropospheric ozone above Europe. Part II: Climatological analysis of the last 30 years, Atmos. Envrion., 39, 5423-5435, 2005.

Colette, A., Ancellet, G., and Borchi, F.: Impact of vertical transport processes on the vertical layering of tropospheric ozone above
Europe. Part I: Study of air mass origin using multi-variate analysis and clustering, Atmos. Envrion., 39, 5409-5422, 2005.

Derwent, R., Jenkin, M., Saunders, S., Pilling, M., Simmonds, P., Passant, N., Dollard, G., Dumitrean, P., and Kent, A.: Photochemical ozone formation in North West Europe and its control, Atmos. Environ., 37(14), 1983-1991, 2003.

Derwent, R., Stevenson, D., Collins, W., and Johnson, C.: Intercontinental transport and the origins of the ozone observed at surface sites in Europe, Atmos. Environ., 38(13), 1891-1901, 2004.

Fischer, H., Lawrence, M., Gurk, C., Hoor, P., Lelieveld, J., Hegglin, M., Brunner, D., and Schiller, C.: Model simulations and aircraft measurements of vertical, seasonal and latitudinal $\mathrm{O}_{3}$ and CO distributions over Europe, Atmos. Chem. Phys., 6, 339-348, 2006, http://www.atmos-chem-phys.net/6/339/2006/.

IPCC: Climate change 2001: The Scientific Basis. Contribution of Working Group I to the Third Assessment Report of the Intergovernmental Panel on Climate Change, edited by: Houghton, J. T., Ding, Y., Griggs, D. J., Noguer, M., van der Linden, P. J., Dai, X., Maskell, K., and Johnson, C. A., Cambridge University Press, Cambridge, United Kingdom and New York, NY, USA, 881 pp., 2001.

Jeannet, P., Stübi, R., Levrat, G., Viatte, P., and Staehelin, J.: Ozone balloon soundings at Payerne (Switzerland): Reevaluation of the time series 1967-2002 and trend analysis, J. Geophys. Res., 112, D11302, doi:10.1029/2005JD006 862, 2007.

Jonson, J., Simpson, D., Fagerli, H., and Solberg, S.: Can we explain the trends in European ozone levels?, Atmos. Chem. Phys., 6, 51-66, 2006,

http://www.atmos-chem-phys.net/6/51/2006/.

Logan, J.: Trends in the vertical distribution of ozone: An analysis of ozonesonde data, J. Geophys. Res., 99(D12), 25 553-25 586, 1994.

Marenco, A., Gouget, H., Nédélec, P., and Pagès, J.-P.: Evidence of a long-term increase in tropospheric ozone from Pic du Midi data series. Consequences : Positive radiative forcing, J. Geophys. Res., 99(D8), 16617-16632, 1994.

Marenco, A., Thouret, V., Nédélec, P., Smit, H., Helten, M., Kley, D., Karcher, F., Simon, P., Law, K., Pyle, J., Poschmann, G., von Wrede, R., Hume, C., and Cook, T.: Measurement of ozone and water vapour by Airbus in-service aircraft: The MOZAIC airborne program, An overview, J. Geophys. Res., 103(D19), 25 631-25 642, 1998.

Monks, P.: A review of the observations and origins of the spring maximum, Atmos. Environ., 34(21), 3545-3561, 2000.

Naja, M., Akimoto, H., and Staehelin, J.: Ozone in background and photochemically aged air over central Europe: Anlysis of longterm ozonesonde data from Hohenpeissenberg and Payerne, J. Geophys. Res., 108(D2), 4063-4073, 2003.

Nédélec, P., Cammas, J., Thouret, V., Athier, G., Cousin, J., Legrand, C., Abonnel, C., Lecoeur, F., Cayez, G., and Marisy, C.: An improved infrared carbon monoxide analyser for routine measurements aboard commercial Airbus aircraft: technical validation and first scientific results of the MOZAIC III program, Atmos. Chem. Phys., 3, 1551-1564, 2003, http://www.atmos-chem-phys.net/3/1551/2003/.

Oltmans, S., Lefohn, A., Harris, J., Galbally, I., Scheel, H., Bodeker, G., Brunke, E., Claude, H., Tarasick, D., Johnson, B., Simmonds, P., Shadwick, D., Anlauf, K., Schmidlin, F., Fuji- 
moto, T., Akagi, K., Meyer, C., Nichol, S., Davies, J., Redondas, A., and Cuevas, E.: Long-term changes in tropospheric ozone, Atmos. Environ., 40, 3156-3173, 2006.

Ordóñez, C.: Trend analysis of ozone and evaluation of nitrogen dioxide satellite data in the troposphere over Europe, Ph.D. thesis, Swiss Federal Institute of Technology Zurich, 2006.

Ordóñez, C., Mathis, H., Furger, M., Henne, S., Hüglin, C., Staehelin, J., and Prévôt, A.: Changes of daily surface ozone maxima in Switzerland in all seasons from 1992 to 2002 and discussion of summer 2003, Atmos. Chem. Phys., 5, 1187-1203, 2005, http://www.atmos-chem-phys.net/5/1187/2005/.

Ribas, A. and Peñuelas, J.: Temporal patterns of surface ozone levels in different habitats of the North Western Mediterranean basin, Atmos. Environ., 38, 985-992, 2004.

Scheel, H., Areskoug, H., Geiss, H., Gomiscek, B., Granby, K., Haszpra, L., Klasinc, L., Kley, D., Laurila, T., Lindskog, A., Roemer, M., Schmitt, R., Simmonds, P., Solberg, S., and Toupance, G.: On the Spatial Distribution and Seasonal Variation of Lower-Troposphere Ozone over Europe, J. Atmos. Chem., 28, 11-28, 1997.

Schuepbach, E., Zanis, T. F. P., Monks, P., and Penkett, S.: State space analysis of changing seasonal ozone cycles (1988-1997) at Jungfraujoch (3580 m asl) in Switzerland, J. Geophys. Res., 106(D17), 20 413-20 428, 2001.

Simmonds, P., Derwent, R., Manning, A., and Spain, G.: Significant growth in surface ozone at Mace Head, Ireland, 1987-2003, Atmos. Environ., 38(28), 4769-4778, 2004.

Staehelin, J., Thudium, J., Buehler, R., Volz-Thomas, A., and Graber, W.: Trends in surface ozone concentrations at Arosa (Switzerland), Atmos. Environ., 28(1), 75-87, 1994.
Thouret, V., Marenco, A., Logan, J., Nédélec, P., and Grouhel, C.: Comparisons of ozone measurements from the MOZAIC airborne program and the ozone sounding network at eight locations, J. Geophys. Res., 103(D19), 25 695-25 720, 1998.

Vautard, R., Honoré, C., Beekmann, M., and Rouil, L.: Simulation of ozone during the August 2003 heat wave and emission control scenarios, Atmos. Environ., 39, 3291-3303, 2005.

Vestreng, V., Adams, M., and Goodwin, J.: Inventory review 2004: Emission data reported to CLRTAP and under the NEC directive, EMEP/MSC-W status report 1/04, The Norwegian Meteorological Institute, Oslo, Norway, 2004.

Vingarzan, R.: A review of surface ozone background levels and trends, Atmos. Environ., 38, 3431-3442, 2004.

Zaveri, R., Saylor, R., Peters, L., McNider, R., and Song, A.: A model investigation of summertime diurnal ozone behaviour in rural mountainous locations, Atmos. Environ., 29(9), 10431065, 1995.

Zbinden, R., Cammas, J.-P., Thouret, V., Nédélec, P., Karcher, F., and Simon, P.: Mid-latitude Tropospheric Ozone Columns from the MOZAIC program: climatology and interannual variability, Atmos. Chem. Phys., 6, 1053-1073, 2006, http://www.atmos-chem-phys.net/6/1053/2006/.

Zellweger, C., Forrer, J., Hofer, P., Nyeki, S., Schwarzenbach, B., Weingartner, E., Ammann, M., and Baltensperger, U.: Partitioning of reactive nitrogen (NOy) and dependence on meteorological conditions in the lower free troposphere, Atmos. Chem. Phys., 3, 779-796, 2003, http://www.atmos-chem-phys.net/3/779/2003/. 